\title{
Fracture of upper incisors: a three-year follow-up of a multidisciplinary approach
}

\author{
Fratura em incisivos centrais superiores: tratamento \\ multidisciplinar com acompanhamento clinico de três anos
}

\author{
Ricardo Armini CALDAS ${ }^{1}$ iD https://orcid.org/0000-0002-5362-4744 \\ Henrique Heringuer VIEIRA ${ }^{2}$ \\ Lucas Alves MOURA ${ }^{3}$ \\ Atais BACCHI ${ }^{4}$ iD https://orcid.org/0000-0002-9913-8290

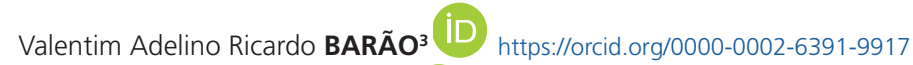 \\ Débora Alves Nunes Leite LIMA² iD https://orcid.org/0000-0001-5457-3347
}

\section{ABSTRACT}

Multiple clinical specialties are usually needed for a successful long-term treatment in buccal cavity. The aim of this article is to report a clinical case of multi-disciplinary rehabilitation of fracture upper incisors without pulp exposure, concerning about endodontics, periodontics and restorative dentistry comments or procedures. A case of a patient reporting trauma that resulted in fracture and substantial loss of hard tissue, in mesial angle of both upper central incisors (11 and 21). In palatal side, fracture extended beyond cingulum up to subgingival region. Periodontal surgery was performed in order to reestablish biological space. Clinical and radiographic assessments demonstrated no need for endodontic treatment, since pulp was vital and non-altered. Preparations for restorative procedures were minimally invasive, followed by composite direct. A three-year follow-up was performed, consisting in re-assessment of clinical and radiographic aspects, re-polishing of the restorations and photographic documentation. No pulp tissue alteration was observed after the follow-up period. Restorative procedures, adjacent tissues and pulp vitality were considered adequate, and the patient was satisfied with the treatment.

Indexing terms: Composite resins. Dental restorations, permanent. Follow up study.

\section{RESUMO}

O objetivo deste artigo é relatar um caso clínico de reabilitação de incisivos superiores fraturados sem exposição pulpar, com considerações na área de endodontia, periodontia e dentística restauradora. O caso relata um trauma que resultou em perda substancial de tecido dentário em ângulo mesial de ambos os incisivos centrais superiores. Na parede palatina, a fratura se estendeu

$\checkmark v \nabla$

${ }^{1}$ Universidade Federal de Santa Catarina, Departamento de Odontologia. Av. Delfino Conti, 1240, 88040-535, Florianópolis, SC, Brasil. Correspondence to: RA CALDAS. E-mail: <Ricardo.caldas@ufsc.br>.

2 Universidade Estadual de Campinas, Faculdade de Odontologia, Departamento de Odontologia Restauradora. Piracicaba, SP, Brasil.

3 Universidade Estadual de Campinas, Faculdade de Odontologia, Departamento de Prótese e Periodontia. Piracicaba, SP, Brasil.

${ }^{4}$ Faculdade Meridional, Curso de Odontologia. Passo Fundo, RS, Brasil.

$\boldsymbol{\nabla} \boldsymbol{\nabla} \boldsymbol{\nabla}$

How to cite this article

Caldas RA, Vieira HH, Moura LA, Bacchi A, Barão VAR, Lima DANL. Fracture of upper incisors: a three-year follow-up of a multidisciplinary approach. RGO, Rev Gaúch Odontol. 2021;69:e2021009. http://dx.doi.org/10.1590/1981-86372021000920190008 
além do cíngulo até a região subgengival. A cirurgia periodontal foi realizada para restabelecer o espaço biológico. As avaliações clínicas e radiográficas não demonstraram necessidade de tratamento endodôntico, pois a polpa se apresentava vital e sem alterações. Os procedimentos restauradores foram minimamente invasivos através da realização de restauração direta com resina composta. Foi realizado acompanhamento de três anos, consistindo em reavaliação dos aspectos clínicos e radiográficos, polimento das restaurações e documentação fotográfica. Nenhuma alteração do tecido pulpar foi observada após o período de acompanhamento. Os procedimentos restauradores, tecidos adjacentes e vitalidade pulpar foram considerados adequados e a paciente demonstrou satisfação com o tratamento.

Indexing terms: Resinas compostas. Restauração dentária permanente. Seguimentos.

\section{INTRODUCTION}

Treatment of dental fractures often involves different dental specialties due to its complexity. Dental element fracture is one type of trauma that may affect patient's health, and can be classified as: enamel fracture, crown fracture (with or without pulp involvement), crownroot fracture (with or without pulp involvement) and root fracture [1]. The most affected teeth are the upper incisors, which fractures involving enamel and dentin are the most common trauma related by dentists [2]. Nowadays, dental trauma is considered an issue of public health, including $5 \%$ of all injuries that leads to dental treatment [3].

Dental trauma impact may affect pulp and periodontal tissues, as well as surrounding alveolar bone [4]. Those damages should be evaluated, not only by clinical assessment, but also by complementary image assessments. Periodontal tissue could be directly affected when fractures extends along biological width [1], resulting in chronic gingival inflammation and, subsequently, bone loss. In order to reduce this process, clinical procedures aiming to recover biological space previously to restorative treatments are mandatory [5].

Hard tissue damage caused by fractures in anterior teeth may lead to aesthetic alterations, with a direct impact in patient's psychological and social aspects [6]. Restorative procedure success depends directly on the association of both function and esthetics reestablishment, especially for anterior region cases.

For this clinical case, root-crown fractures of teeth 11 and 21 (without pulpal involvement) are reported. Crown-lengthening procedures were required in palatal region for both teeth.

\section{CASE REPORT}

A patient (41 years old, female) attended to Piracicaba Dental School Clinic with substantial loss of hard tissue in mesial angle of both upper central incisors (11 and 21) (figure 1A). The patient reported a trauma caused by hitting a glass door resulting in multiple fragments (the fragments were lost) one day before dental assistance. In palatal side, fracture extended beyond cingulum up to subgingival region (figure 1B). At the beginning of clinical intervention, the patient was clarified about the procedures and agreed to document the case for publication.

Periapical radiography indicated no damages to surrounding tissues, with normal periodontal ligament width and absence of fractures in alveolar bone (figure 1C). Combined with radiographs and clinical examination, pulp

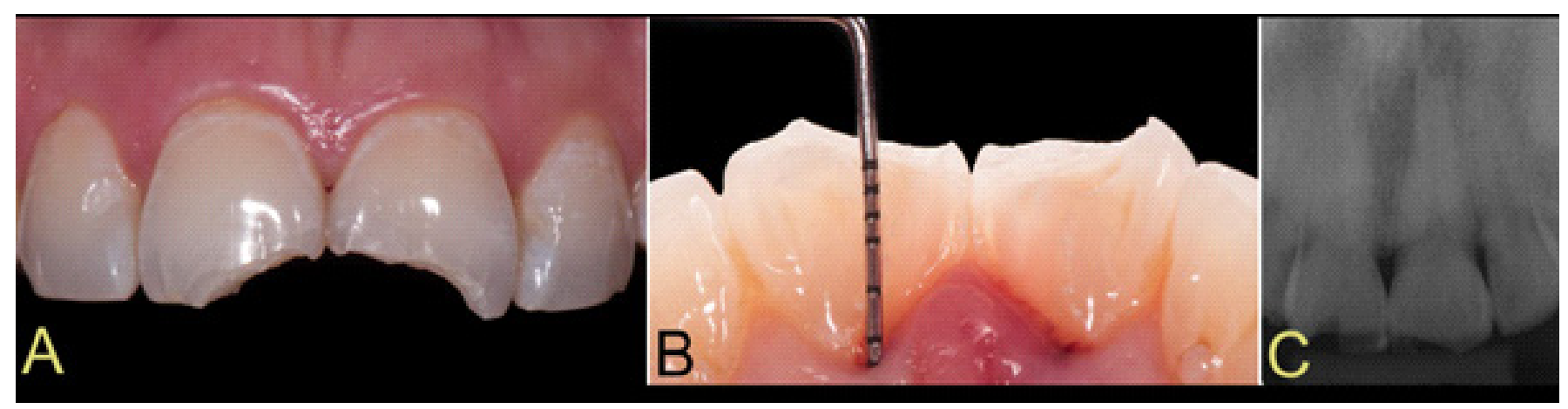

Figure 1. A) Front view of fractured incisors; B) Periodontal evaluation; C) Initial radiography. 
vitality test indicated that pulp tissue was not compromised. During clinical exam, fragments were observed in palatal wall (attached to periodontal ligament) for both teeth. Fragments were removed after local anesthesia.

After the periodontal evaluation was observed a need for surgery to restore biological width prior to restorative treatment in both affected teeth. Surgical procedure consisted of internal bevel incision, resulting in a soft tissue collar that would be removed to establish the new position of gingival margin. After collar removal a flap of total thickness was raised, exposing root and bone. Osteotomy and osteoplasty were performed using a carbide bur under constant irrigation of sterile saline solution attached to a high-speed handpiece (figure 2A) and a manual instrument (Ochsenbein micro-chisel, Hu- Friedy, Chicago, IL, EUA) (figure 2B). Sutures (Mononylon Ethycon 5-0, Johnson-Johnson, São José dos Campos, SP, Brazil) were made toward palatal side to not be exposed during smile (figure 2C). Patient reported discomfort during treatment, leading to aesthetic provisional restorations made with resin modified glass ionomer cement (Vitremer, 3M ESPE, Sumaré, SP, Brazil).

After a week from surgical procedures, impression was made using irreversible hydrocolloid (alginate). Waxup was performed for elements 11 and 21, on the cast, in order to create a PVS barrier (putty) for guiding anterior restoration of palatal and incisal regions. After 45 days (healing of periodontal tissues), restorative procedures were performed. Shade selection of composite resins was performed with teeth still hydrated, prior to complete isolation of operative field. With teeth adequately isolated, temporary restoration were removed, and preparation was performed, including an enamel bevel using a fine-grained diamond bur (FG 2135, KG Sorensen, Cotia, SP, Brazil).
All restorative procedures were performed for both dental elements simultaneously. After complete removal of temporary restorations and preparations, PVS guide was positioned, in order to check the adaptation.

Bonding procedures were performed by using a total-etch 2-steps adhesive system (Adper Single Bond 2, 3M ESPE, Sumaré, SP, Brazil). First, enamel was etched with $37 \%$ phosphoric acid gel (Condac 37, FGM, Joinville, SC, Brazil) for 15 seconds, followed by etching the entire preparation (including dentin) for extra 15 seconds, resulting in 30 seconds etching time for enamel, and 15 seconds for dentin. Teeth were water rinsed by the same time as they were etched, in order to remove the acid gel. Enamel was air-dried and the dentin substrate was kept moist (controlled by a humid cotton pellet), for maintaining hydration of collagen fibers. Adhesive system was applied in two subsequent layers, followed by a gentle air blow for 5 seconds, allowing the solvent to evaporate. Adhesive system was light cured by a monowave LED light curing unit (Radii Cal, SDI, Australia) for 20 seconds

Restorative procedures were carried out by using a stratified incremental technique (Empress Direct, Ivoclar Vivadent, Barueri, SP, Brazil). In order to obtain palatine wall, a thin layer of translucent resin was applied onto the PVS guide and placed on preparations (figure 3A). Composite was light-cured (with PVS guide in position) and carefully removed, in order to avoid fractures in the composite. Dentin portion was restored following this substrate characteristics, with more saturated and opaque composites (figure 3B). Subsequently, small increments with composites that simulate opalescent effect were applied (figure 3C). Last increment consisted of a single translucent resin covering all restoration, including enamel bevel preparation (figure 3D).
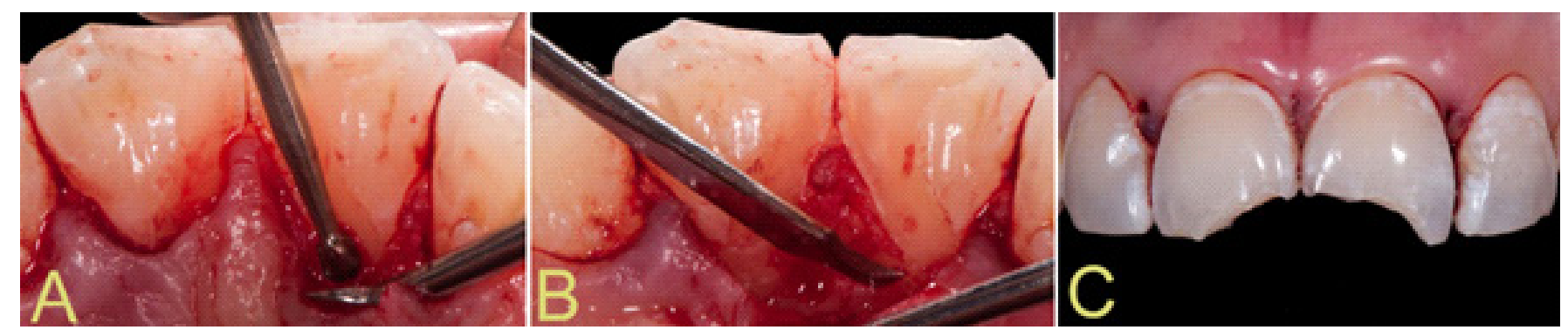

Figure 2. A) Osteotomy with carbide drill; B) Osteoplasty with Ochsenbein micro-chisel; C) Immediate aspect after suture. 

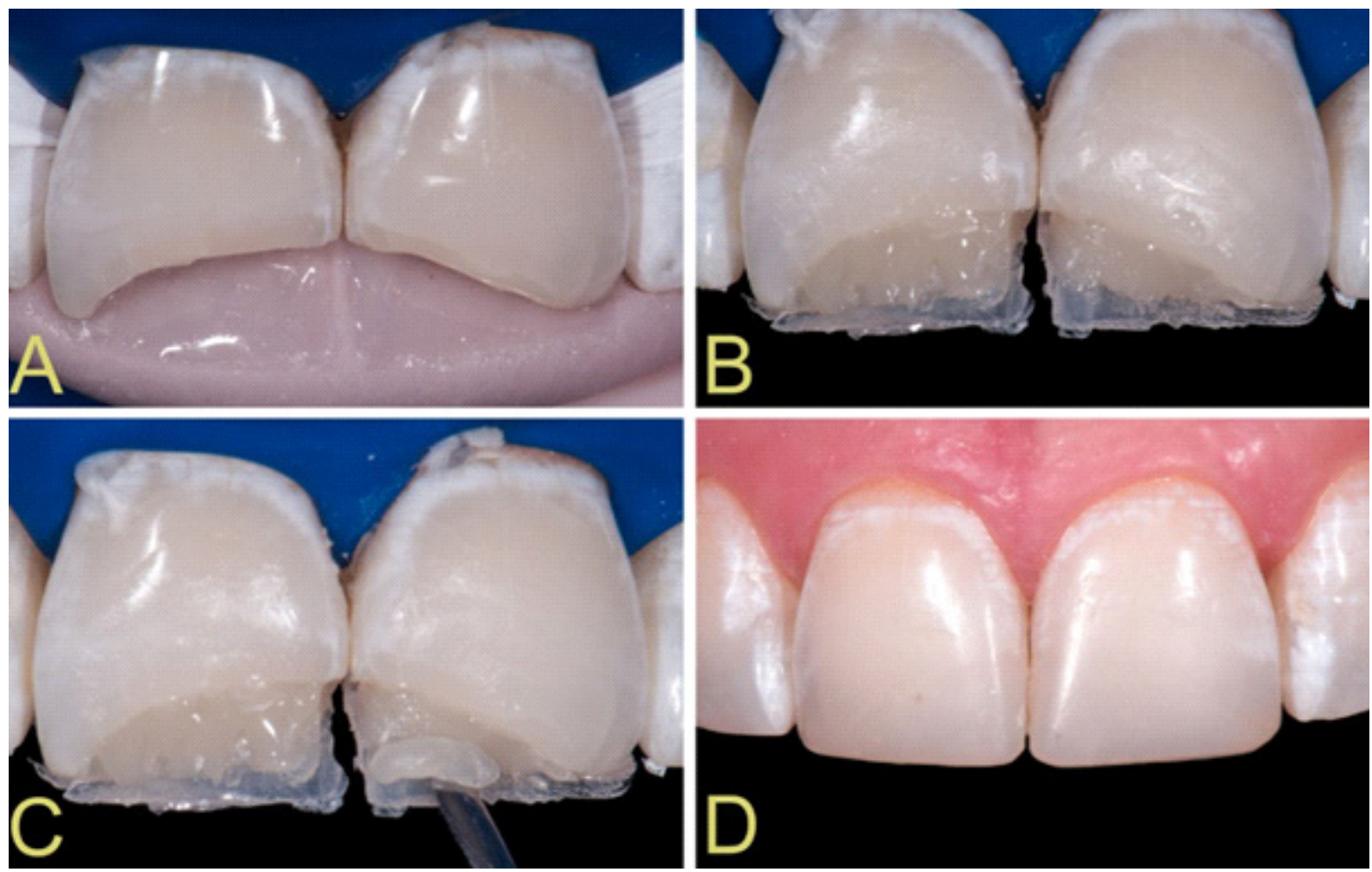

Figure 3. A) Translucent resin layer in position before polymerization; B) Opaque resin layer simulating the dentin tissue; C) Application of the opalescent resin. D) Complete restorations.

Rubber dam was removed, then the occlusal contacts were checked in maximum intercuspation and protrusive movements. Patient remained seated to remove any inappropriate contact. In this same appointment, finishing procedures were performed to remove any excess or roughness of the restoration. Patient returned after one week, where restorations were reevaluated and polished. Patient demonstrated high acceptance of the esthetic and functional results.

After three years, patient returned for a routine clinical follow-up. Clinical assessment, radiographic evaluation and pulpal vitality tests, (figure 4A) showed a healthy
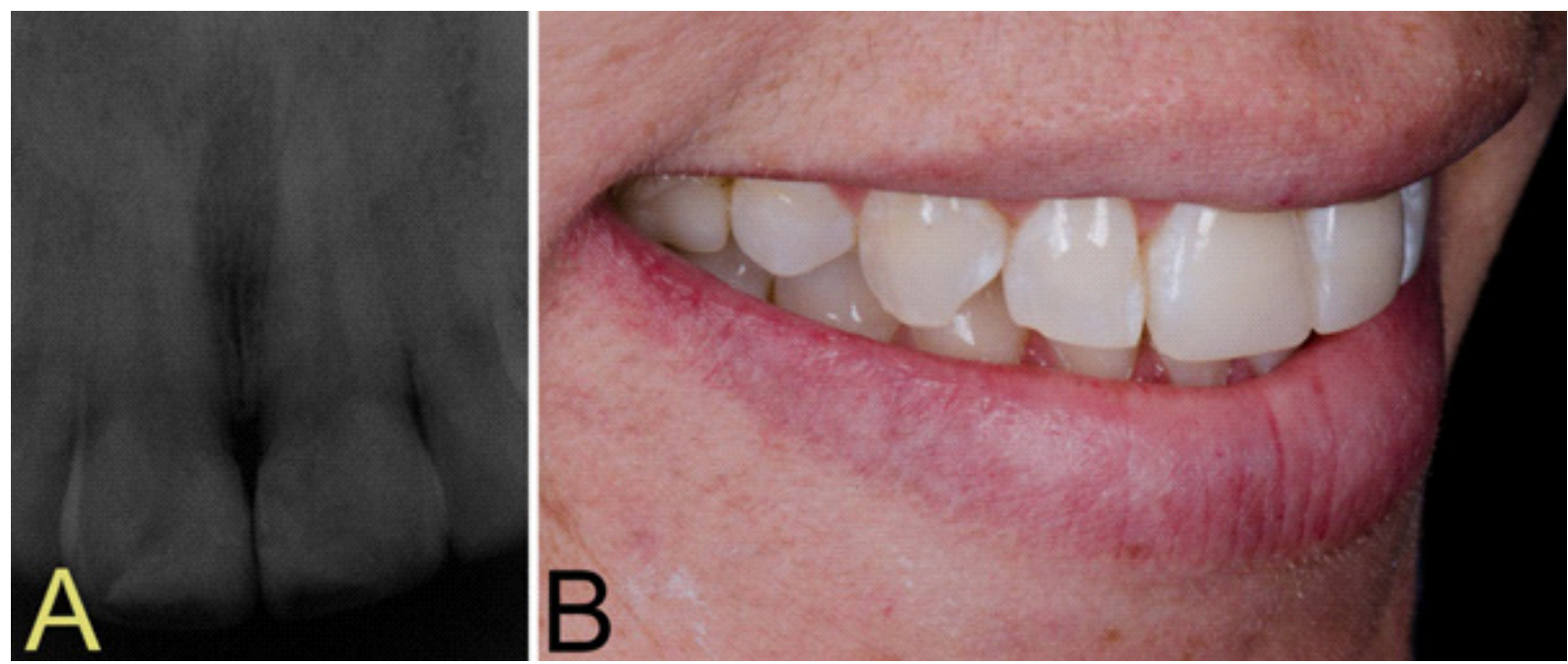

Figure 4. A) Three-year control radiography showing the health of the supporting tissues; B) Three-year control. After a new polishing restorations continue with proper function and aesthetics. 
condition with no periodontal inflammation or pulp necrosis. Restoration was re-polished using finishing discs (Sof-Lex, 3M ESPE, Sumaré, SP, Brazil) followed by silicon carbide brush (Astrobrush, Ivoclar Vivadent, Barueri, SP, Brazil). After re-polishing procedures of the composite restoration, pictures were taken for documentation and comparison with initial aspect (figure 4B).

\section{DISCUSSION}

In cases of trauma with loss of coronal tooth structure, it is possible to perform bonding procedures if the fragment is still present. However, this technique presents some limitations such as multiple fracture fragments, mismatch fragment or even loss of parts of the structure [1]. Fragment bonding is not possible when the fragment is stored improperly. Dental fragments lose bond strength when they are dehydrated for more than an hour. Therefore, the decrease in bond strength is reversible by rehydration if the fragment is immersed in water for 24 hours. However, the period for rehydrating the fragment makes the clinical process unfeasible because the patient would have to wait for treatment. Furthermore, the aesthetics of the fragment is not restored after rehydration as it becomes opaque [7]. In the presented case, the fragment bonding could not be performed due to the loss of fragments on the part of the patient, who reported multiple fractures. After examination of the amount of remaining tooth structure, it was decided that a direct restorative treatment with aesthetic composite resin was the best option.

In adults, dental trauma often results in tooth fractures, whereas in growing patients tooth dislocation is most common due to differences in alveolar bone stiffness [8]. Depending on factors such as location, strength and direction of impact, the trauma can also affect the surrounding tissues (e.g. periodontal and alveolar bone) as well as the dental organ. Dental concussion, subluxation, dislocations, intrusion, extrusion or avulsion are some possible injuries, requiring specific treatment for each case $[9,10]$. The dentist should diagnose the affected dental structures and then elaborate an individualized treatment plan. This should take into account factors such as affected tissues and presence or absence of pain [5]. Patients usually attend the clinic soon after the trauma, reporting presence of pain. In this scenario, the first procedure is to alleviate the suffering of the patient before making the correct diagnosis of the cause of pain. In this case, the patient reported presence of pain. After clinical and radiographic analysis, it was found that sensitivity was related to dentin exposed to the oral environment, without painful involvement of the periapical region.

Crown fractures without pulp involvement leads to exposure of dentinal tubules. Because this exposure can cause damage to pulp tissue, it is necessary to seal the tubules in the first appointment [1]. This prevents contamination of the pulp chamber by bacteria and reduces the transmission of harmful stimuli and painful sensitivity. As the dentin approaches the pulp chamber, the dentinal tubules increase both in quantity and thickness, so the closer the fracture is to the pulp, the greater the chance of pain and contamination of the pulp tissue [11].

When the fracture extends into the periodontal region as in the present case, it is necessary a crownlengthening surgery to restore the biological width prior to restorative treatment, thus avoiding future damage to the periodontal tissue. When the restoration extends along the biological width, the body reacts destructively. This reaction takes place through constant inflammation of the area, which can be caused by bacterial colonization in the restoration. Clinically, these reactions can cause insertion failure with bone loss and gingival recession [5].

Other factors which may adversely affect the practitioner's performance are anxiety and stress of the patient, especially when he or she is restless. Occasionally, the postponement of the final restoration may be the best option for the case. There are currently restorative materials which can be used for temporary restoration with acceptable aesthetic function, such as the resin-modified glass ionomer. This type of procedure has the advantage of being faster compared to composite resin restorations. The resin-modified glass ionomer allows for color selection and can simulate the color and shape of the patient's teeth. Moreover, this material exhibits chemical bonding characteristics similar to those of the dental substrate [12], providing protection of the pulp-dentin complex and immediate pain relief caused by tooth exposure.

When performing the restoration in two steps such as presented here - temporary restoration in the first appointment and final restoration in the second - the practitioner has time for a more accurate planning. The study of a cast model and use of silicone barrier to be used as a template for tooth anatomy increase the predictability of the restorative treatment. To properly restore the dental substrate, minimally invasive restorations are always the first 
choice to avoid loss of the tooth structure. Furthermore, this approach has a lower cost compared to indirect restorations and is able to reproduce the natural dental aesthetics [13]. A stratified technique performed with composite resin is the best option, starting with the palatal wall and creating a support for other layers.

Pulp vitality tests should be always performed in the follow-up visits to check whether there is any alteration in the period of restoration, with radiographic evaluations being important to assess adjacent tissues. In addition, radiographs should be taken routinely to evaluate the restoration and its marginal interaction with dental substrate. A careful clinical examination of the periodontal protection should also be performed, especially on the face where the biological width was re-established. In this case, the palatal face is close to the edge of both restoration and soft tissue.

The polishing procedure can remove the surface pigmentation and restore glow to composites. Thus, the polishing of restorations should be performed as part of the protocol for maintenance of resin composites. Composite resin restorations in anterior teeth have a low failure rate, with occasional failures being usually related to poor aesthetics [14]. Therefore, the maintenance of resin restoration by polishing becomes a factor for longevity of the treatment. In this case, even after 3 years, the restoration depended on loss of surface polishing and discrete surface staining. These problems have been solved with polishing as described in the case report.

In cases of dental fracture with aesthetic involvement, the dentist should always keep in mind that in addition to the technical parameters of the restorative procedure, the patient's psychological factors should also be considered after a sudden change in the smile. Therefore, the treatment for this type of trauma should be performed as quickly as possible by restoring the tooth either temporarily or even permanently, but always taking into account pulp and periodontal aspects. Thus, the practitioner should not remove any healthy tooth structure and ensure the longevity of a direct restorative treatment with composite resin [13].

\section{CONCLUSION}

Therefore, the two-step treatment of anterior fractured teeth with composite resin is an aesthetic and functional therapy resulting in adequate longevity. In addition, the interaction between periodontal status and restorative procedures should be taken into account to ensure a successful treatment.

\section{Collaborators}

RA CALDAS and HH VIEIRA, clinics, main text, photography. LA MOURA, clinics, periodontics review, main text. A BACCHI, main text development, review. VAR BARÃO, dental materials review, main text. DANL LIMA, restorative dentistry review, main text.

\section{REFERENCES}

1. Chauhan R, Rasaratnam L, Alani A, Djemal S. Adult Dental Trauma: What Should the Dental Practitioner Know? Prim Dent J. 2016 Aug 1;5(3):70-81. http://dx.doi.org/10.1177/2 05016841600500308

2. Hecova $H$, Tzigkounakis $V$, Merglova $V$, Netolicky J. A retrospective study of 889 injured permanent teeth. Dent Traumatol. 2010 Dec; 26(6):466-75. http://dx.doi. org/10.1111/j.1600-9657.2010.00924.x

3. Petersson EE, Andersson L, Sörensen S. Traumatic oral vs non-oral injuries. Swed Dent J. 1997;21(1-2):55-68.

4. Soares DA, Tulio MAP, Westphalen FH, da Silva Neto UX, Kowalczuck A, Carneiro E, et al. Management of Multiple Dental Trauma: Case Report with Eight-Year Follow-up. Iran Endod J. 2018;13(3):410-2. http://dx.doi.org/10.22037/iej. v13i3.21090

5. Juloski J, Köken S, Ferrari M. Cervical margin relocation in indirect adhesive restorations: A literature review. J Prosthodont Res. 2018 Jul;62(3):273-80. http://dx.doi. org/10.1016/j.jpor.2017.09.005

6. Magno MB, Jural LA, Nogueira AV, Lenzi MM, Pithon MM, Maia LC. Impact of crown fracture treatment on oral healthrelated quality of life of children, adolescents, and their families: A prospective clinical study. Int J Paediatr Dent. 2019 Jan; 29(1):86-93.

7. Vodoriz YY, Marchenko IY, Shyndryk MA, Tkachenko IM. Review of treatment methods of patients with uncomplicated teeth fractures. Wiad Lek. 2018;71(7):1360-4. http://dx.doi org/10.1590/S1677-32252013000400002

8. Schatz JP, Joho JP. A retrospective study of dento-alveolar injuries. Endod Dent Traumatol. 1994 Feb;10(1):11-4. http:// dx.doi.org/10.1111/j.1600-9657.1994.tb00591.x

9. Andreasen JO, Lauridsen E, Gerds TA, Ahrensburg SS. Dental Trauma Guide: A source of evidence-based treatment guidelines for dental trauma. Dent Traumatol. 2012 Oct; 28(5):345-50. http://dx.doi.org/10.1111/j.16009657.2011.01059_1.X

10. Kenny KP, Day PF, Sharif MO, Parashos P, Lauridsen E, Feldens $C A$, et al. What are the important outcomes in traumatic 
dental injuries? An international approach to the development of a core outcome set. Dent Traumatol. 2018 Feb;34(1):4-11. http://dx.doi.org/10.1111/edt.12367

11. Brizuela C, Ormeño A, Cabrera C, Cabezas R, Silva $\mathrm{Cl}$, Ramírez V, et al. Direct Pulp Capping with Calcium Hydroxide, Mineral Trioxide Aggregate, and Biodentine in Permanent Young Teeth with Caries: A Randomized Clinical Trial. J Endod. 2017 Nov;43(11):1776-80. http://dx.doi.org/10.1016/j. joen.2017.06.031

12. Kampanas N-S, Antoniadou M. Glass lonomer Cements for the Restoration of Non-Carious Cervical Lesions in the Geriatric Patient. J Funct Biomater. 2018 Jul 8;9(3):42. http:// dx.doi.org/10.3390/jfb9030042
13. Sugii MM, Caldas RA, Gouvea THN, Lima DANL, Marchi GM, Aguiar FHB. Utilizing the optical properties of composite resins to improve esthetics: a layering technique for anterior restorations. Gen Dent. 2019;67(1):55-60.

14. Demarco FF, Collares K, Coelho-de-Souza FH, Correa MB, Cenci MS, Moraes RR, et al. Anterior composite restorations: A systematic review on long-term survival and reasons for failure. Dent Mater. 2015 Oct;31(10):1214-24. http://dx.doi. org/10.1016/j.dental.2015.07.005

Received on: 13/5/2019

Final version resubmitted on: 16/10/2019

Approved on: 22/3/2021 